\title{
KULTURNATION KONTRA VERFASSUNGSNATION - HISTORYCZNY SPÓR WOKÓŁ OBYWATELSTWA I NARODOWOŚCI W NIEMCZECH
}

\begin{abstract}
Hildebrandt-Wypych Dobrochna, Kulturnation kontra Verfassungsnation - historyczny spór wokót obywatelstwa i narodowości w Niemczech [Kulturnation versus Verfassungsnation - a Historical Debate About Citizenship and Nationality in Germany]. Studia Edukacyjne nr 40, 2016, Poznań 2016, pp. 69-88. Adam Mickiewicz University Press. ISSN 1233-6688. DOI: 10.14746/se.2016.40.5

The almost entirely elite-driven liberalization of the right to acquire citizenship collides currently with the increasingly xenophobic sentiments and openly anti-immigrant movements among the general public all over Europe. Even in Germany discussions about the liberalization of citizenship law in the late 1990s have become a symbolic part of the dispute between supporters of ethnocentric Kulturnation (the cultural nation) and the advocates of civic Verfassungsnation (the constitutional nation). The article presents the historical context of the development of the German citizenship policy. It also raises the question of the possibility to create and legitimize - on the basis of liberalized regulations of the law on citizenship - new definitions of a symbolic membership in a civic community, located outside the traditional, ethnically based citizenship regime.
\end{abstract}

Key words: citizenship law, citizenship policy, cultural nation, constitutional nation, Germany, policy change

Celem artykułu jest opis i wyjaśnienie procesu rozwoju niemieckiej polityki obywatelstwa. Temat podjęty został z dwóch powodów: jako egzemplifikacja "etnicznego" podejścia do definiowania przynależności narodowej oraz jako ilustracja powiązania teorii i praktyki „włączania do wspólnoty obywateli" przybywających coraz liczniej do Europy osób odmiennych kulturowo. W perspektywie pozostaje istotny, obecny już od kilku dekad, choć zyskujący współcześnie na znaczeniu, problem integracji imigrantów w europejskich społeczeństwach przyjmujących. 
Sterowana $\mathrm{z}$ poziomu elit liberalizacja prawa nabywania obywatelstwa zderza się obecnie z coraz silniejszymi nastrojami ksenofobicznie i otwarcie antyimigracyjnymi. Opór wobec wprowadzonej pod koniec lat 90 . XX wieku liberalizacji staje się symboliczną częścią sporu między zwolennikami etnocentrycznego Kulturnation (narodu kulturowego) a stronnikami obywatelskiego modelu Verfassungsnation (narodu konstytucyjnego), który obecny jest $\mathrm{w}$ niemieckiej sferze publicznej po dziś dzień.

Artykuł przedstawia historyczny kontekst rozwoju niemieckiej polityki obywatelstwa, stawiając jednocześnie pytanie o możliwość wykreowania na bazie zliberalizowanych przepisów o nabywaniu obywatelstwa - nowej definicji „niemieckości” w przestrzeni publicznej.

\section{Naród kulturowy kontra naród polityczny}

Naród (Volk1) uznawany był za strukturę społeczną poprzedzającą państwo. W przeciwieństwie do narodu politycznego, którego członków łączy wspólnota ustanowionego przez państwo w konstytucji uniwersalnego zestawu praw i obowiązków, naród kulturowy można określić jako „wspólnotę komplementarnych nawyków komunikowania się" 2 . Tak było właśnie w Niemczech, gdzie poczucie przynależności do kulturowo definiowanej wspólnoty narodowej wsparte zostało na gotowości jej członków do pielęgnowania dziedzictwa kulturowego minionych pokoleń. Jak pisał Karl Wolfgang Deutsch, naród to „rozległa, uniwersalna sieć komunikacyjna” (Allzweck-Kommunikationsnetz), łącząca ludzi posługujących się tym samym językiem i - dzięki posiadaniu porównywalnych nawyków komunikacyjnych - w pokrewny sposób interpretujących elementy otaczającej rzeczywistości oraz nawiązujących do podobnych wspomnień ${ }^{3}$.

${ }^{1}$ Niemiecki słownik demograficzny z 1960 r. definiuje Volk jako „grupę ludzi o wspólnych fizycznych, językowych i kulturowych cechach, która w toku historycznego rozwoju osiągnęła świadomość swej wspólnoty". Pojęcie Volk definiuje się niekiedy jako naród w wymiarze etnicznym, w przeciwieństwie do pojęcia Nation, będącego narodem w sensie politycznym. Jednak w niemieckiej ustawie zasadniczej pojęciu Volk nadano podwójne znaczenie, zarówno etniczne (jako wspólnoty kultury, języka i historii), jak i polityczne (jako „narodu politycznego" - Staatsnation); por. S. Cholewiak, Nacjonalizm w partiach zachodnioniemieckich, Warszawa 1984, s. 35-37.

${ }^{2}$ M. Hroch, Małe narody Europy. Perspektywa historyczna, Wrocław - Warszawa - Kraków 2003, s. 103.

${ }^{3}$ K.W. Deutsch, Nationenbildung - Nationalstaat - Integration, Düsseldorf 1972, s. 204, w: Nation-Nationalismus-nationale Identität, red. D. Weidinger, Bundeszentrale für politische Bildung, Bonn 1998, s. 23. 
Jak wskazuje A. Bodnar, „Tożsamość polityczna w państwie narodowym opiera się na przynależności do narodu rozumianego jako demos" ${ }^{4}$, czyli jako abstrakcyjnie pojmowany lud - zbiór obywateli, poddający się władzy publicznej i będący źródłem tejże władzy oraz stanowionych przez nią praw. W niemieckiej szkole nauki o państwie obowiązuje "organiczno-kulturowe" rozumienie demos - ludu przedpaństwowego, istniejącego jako „,jednorodna wspólnota posiadająca wspólną historię, pochodzenie kulturowe i narodowe oraz mająca podobne przeznaczenie (tzw. Schicksalgemeinschaft)" 5 . Podczas gdy we francuskiej tradycji „narodu państwowego” przynależność do narodu jest efektem gotowości jednostek do poddania się ustanowionemu przez siebie, opartemu na demokratycznym wyborze rządowi, w niemieckiej tradycji „narodu kulturowego" decydująca dla powstania wspólnoty narodowej nie jest wola polityczna wyrażona przez głosujących obywateli, ale wspólne dla jej członków istnienie "obiektywnych kryteriów”, takich jak język czy kultura. Zamiast - opartej na uniwersalistycznych zasadach i będącej podstawą tzw. „narodu obywateli” - wspólnej kultury politycznej jako podstawy funkcjonowania narodu politycznego, naród kulturowy połączony jest wyobrażonymi „więzami języka, kultury, religii, historii i pragnien"6.

Należy jednocześnie pamiętać, że w historycznym rozwoju poszczególnych wspólnot narodowych trudno precyzyjnie rozdzielić wątki związane z narodem kulturowym i państwowym. Już na początku XX wieku F. Meinecke wskazywał, że w ramach narodu państwowego, na przykład Szwajcarii, mogą funkcjonować, połączone wspólnym dziedzictwem historycznym, językowym i religijnym, pomniejsze narody kulturowe. $Z$ drugiej strony, niemiecki naród kulturowy składa się z wielu narodów państwowych - społeczeństw krajów związkowych, połączonych poczuciem wspólnoty politycznej (politisches Gemeingefühl)7. Założenie o historycznym pierwszeństwie narodu nad państwem wpłynęło na ukonstytuowanie się niemieckiego modelu obywatelstwa. Obywatelstwo niemieckie zależy od wcześniejszej przynależności do wspólnoty etnicznej, a więc jest warunkowane członkostwem $\mathrm{w}$ narodzie niemieckim. Zarówno $\mathrm{w}$ odniesieniu do wewnętrznego statusu członkostwa w państwowej wspólnocie politycznej (Staatsbürgerschaft), jak i w kontekście międzynarodowego uznania przynależności państwowej

${ }^{4}$ A. Bodnar, Obywatelstwo wielopoziomowe. Status jednostki w europejskiej przestrzeni konstytuсуjnej, Warszawa 2008, s. 136.

5 Tamże.

6 S. Brockmann, Nuremberg. The Imagniary Capital, Camden House 2006, s. 9.

${ }^{7}$ F. Meinecke, Weltbürgertum und Nationalstaat, München - Berlin 1919, s. 1-7, w: NationNationalismus-nationale Identität, s. 16. 
(Staatsangehörigkeit), obywatelstwo jest ściśle powiązane z przynależnością etniczną. W niemieckim modelu obywatelstwa zakłada się

że wszyscy obywatele są członkami narodu, a naród jest społecznością nie tylko $\mathrm{w}$ rozumieniu polityczno-prawnym (Staatsnation), lecz także jest społecznością kształtowaną przez wspólne pochodzenie, historię, kulturę, język, które istniały zanim powstało państwo (Volksnation) ${ }^{8}$.

\section{Kontekst historyczny}

Niemieckie państwo narodowe wyłoniło się pod koniec wojny francusko-pruskiej w 1871 roku. Sukces militarny Prus przypieczętował zamiar dążenia do zakończenia - pod przewodnictwem Otto von Bismarcka - procesu zjednoczenia Niemiec. Preludium do jego zakończenia stanowiło uchwalenie w 1867 roku konstytucji Związku Północnoniemieckiego (Verfassung des Norddeutschen Bundes). Proklamacja utworzenia drugiego Cesarstwa Niemieckiego (Deustches Reich) w styczniu 1871 roku, na czele którego stanął Wilhelm I Hohenzollern (jako cesarz Niemiec) oraz Otto von Bismarck (jako kanclerz Rzeszy), zbiegła się w czasie z końcem wojny. Stroną traktatu pokojowego z maja 1871 roku były zjednoczone już Niemcy, na rzecz których Francja musiała przekazać Alzację i północną Lotaryngię 9 . Jak zauważa R. Brubaker, obywatelstwo w pierwszej połowie XIX wieku wyłaniało się jako inspirowany pruskim ustawodawstwem twór przednarodowy i przeddemokratyczny. Od początku istniał czytelny podział na naród i państwo: niemiecką przynależność państwową (narodowość) i pruskie obywatelstwo, rozumiane jako etniczno-kulturowe członkostwo w państwie narodowym ${ }^{10}$.

Choć w 1871 roku Niemcy stały się państwem narodowym, dysponującym obywatelstwem narodowym, siła funkcjonujących na jego terytorium partykularyzmów doprowadziła do wyraźnej „etnicyzacji” obywatelstwa w okresie Rzeszy Wilhelmińskiej (1890-1918). Dostęp do niemieckiego obywatelstwa został oparty wyłącznie na pochodzeniu (ius sanguinis), po raz pierwszy wprowadzonym w 1818 roku w Bawarii, następnie zaadaptowanym dla obszaru całych Prus w 1842, skonsolidowanym poprzez utworzenie zjednoczonych Niemiec w 1871, a ostatecznie ustanowionym niemieckim

\footnotetext{
8 A. Bodnar, Obywatelstwo wielopoziomowe, s. 30.

${ }^{9}$ T. Paluszyński, Historia Niemiec i państw niemieckich. Zarys dziejów politycznych, Poznań 2006, s. 386.

${ }^{10}$ R. Brubaker, Citizenship and Nationhood in France and Germany, Cambridge, Massachusetts, London 1992, s. 51-52.
} 
prawie o obywatelstwie z 1913 roku11. To wówczas wykrystalizowała się ostatecznie niemiecka definicja wspólnoty obywateli jako wspólnoty osób wywodzących się od wspólnych przodków (community of descent). Nowe prawo stało się podstawą nacjonalizacji, wręcz "etnicyzacji” niemieckiego obywatelstwa (przynależności państwowej), było bowiem - jak stwierdza Brubaker - „inkluzywne (włączające) względem emigrantów, a ekskluzywne (wyłączające) względem imigrantów"12. Priorytet tworzenia etnicznie i kulturowo homogenicznego narodu wpływał na restrykcyjne pojmowanie naturalizacji cudzoziemców, w szczególności grup mniejszościowych uważanych za "obce językowo i rasowo" (Sprachen- und Rassenfremde), takich jak Polacy i Żydzi. Wykluczeniu "narodowo obcych” (Volksfremde) ${ }^{13}$ towarzyszyło bezwarunkowe wsparcie etnicznych Niemców z zagranicy (Auslandsdeutche, Volksdeutsche), których nieograniczone prawo do obywatelstwa niemieckiego miało być - jak podkreślał Ernst Hesse, przewodniczący Ligi Pangermańskiej - elementem „szerszego planu przekształcenia Niemiec w prawdziwe państwo narodowe"14. Obowiązujące na początku XX wieku prawo

uczyniło obywatelstwo bardziej dostępnym dla osiadłych na stałe za granicą emigrantów, a mniej dostępnym dla osiadłych na stałe w Rzeszy imigrantów. Tradycyjne niemieckie rozróżnienie na naród i państwo, Volk i Staat, zostało wpisane w obszar prawa o obywatelstwie. Definicja wspólnoty obywatelskiej została znacjonalizowana - zbliżona do etniczno-kulturowego wymiaru narodu, a oderwana od terytorialnego wymiaru państwa. Obywatele byli określani raczej na podstawie koordynatów genealogicznych, aniżeli współrzędnych terytorialnych, raczej przez pochodzenie, aniżeli zamieszkanie ${ }^{15}$.

Historia niemieckiej (zjednoczonej) państwowości jest być może niezbyt długa, ale z pewnością burzliwa. Po I wojnie światowej Rzesza Niemiecka kontynuowała swoje istnienie $w$ ramach demokratycznego państwa federalnego (demokracji parlamentarnej), potocznie nazywanego Republiką We-

${ }^{11}$ M.M. Howard, The Politics of Citizenship in Europe, New York 2009, s. 120.

12 R. Brubaker, Citizenship and Nationhood in France and Germany, s. 114.

${ }^{13} \mathrm{~W}$ ramach zwalczającej dążenia niepodległościowe prusko-niemieckiej polityki polskiej (Polenpolitik), Polacy „byli stygmatyzowani jako Reichfeinde (wrogowie Rzeszy); byli prawnie i administracyjnie traktowani jako obywatele drugiej kategorii" (tamże, s. 128).

${ }_{14}$ Tamże, s. 116. Jak pisze Brubacker, „etno-polityczne zainteresowanie Volksdeutschami poza Rzeszą przyjęło różne formy, od czysto kulturowych wysiłków na rzecz zachowania i wsparcia niemieckich szkół, języka i kultury za granicą, do postulatów interwencji państwa niemieckiego w obronie etnicznych Niemców prześladowanych za granicą, zwłaszcza w rejonie Morza Bałtyckiego oraz na Węgrzech" (tamże, s. 126).

15 Tamże, s. 119. 
imarską. Ta - jak ją nazywali współcześni - „republika bez republikanów” borykała się z wieloma problemami wewnętrznymi, wynikającymi zarówno z bezpośrednich skutków wojny (np. hiperinflacja), jak i z toczących ten niestabilny twór państwowy konfliktów politycznych (monarchistów, lewicowych radykałów, nacjonalistów). Do upadku Republiki Weimarskiej przyczynił się też światowy kryzys gospodarczy 1930 roku, którego skutki były szczególnie odczuwalne $\mathrm{w}$ słabej gospodarce międzywojennych Niemiec. Katastrofalna sytuacja na rynku pracy osłabiała społeczne zaufanie do republiki i wzmacniała zagrożenie kraju wojną domową. Rosnące wpływy polityczne narodowych socjalistów (NSDAP) zakończyły się ostatecznie w marcu 1933 roku w Poczdamie proklamacją państwa o ustroju totalitarnym, czyli Trzeciej Rzeszy16.

Jak podkreśla R. Brubaker:

Bez wątpienia nacjonalizm Republiki Weimarskiej i powstanie nazizmu muszą być rozumiane w kontekście historycznym, a wrzaskliwy, buntowniczy nacjonalizm ery Wilhelmińskiej jest istotną częścią owego kontekstu. (...) istotne jest jednak wyraźne rozróżnienie pomiędzy etno-kulturowym wymiarem reformy prawa o obywatelstwie w Rzeszy Wilhelmińskiej a radykalną etno-rasową restrukturyzacją obywatelstwa za rządów Nazistów ${ }^{17}$.

Zniesieniu kategorii obywatelstwa regionalnego (krajów związkowych) oraz utworzeniu państwa unitarnego towarzyszyło unieważnienie naturalizacji, dokonanych w okresie Republiki Weimarskiej, zwłaszcza wobec tych, którzy „wystąpili przeciwko obowiązkowi lojalności wobec Imperium Niemieckiego oraz $>$ Narodu Niemieckiego $<18$. Następnie, na mocy ustaw norymberskich z 1935 roku, w szczególności na mocy Ustawy o obywatelstwie Rzeszy (Rechbürgergesetz), Żydzi i Romowie - jako nielojalni wobec narodu niemieckiego - mogli zostać pozbawieni obywatelstwa Rzeszy. Ta, nieznana wcześniej, ultraradykalna interpretacja prawa krwi (ius sanguinis) ${ }^{19}$ umożliwiła traktowanie obywatelstwa jako narzędzia do tworzenia hierarchii rasowej i uzasadniania ludobójstwa ${ }^{20}$. Jak pisze Franciszek Ryszka, „społe-

${ }^{16}$ J. Tyszkiewicz, E. Czapiewski, Historia powszechna. Wiek XX, Warszawa 2012.

17 R. Brubaker, Citizenship and Nationhood in France and Germany, s. 166.

${ }^{18}$ M.M. Howard, The Causes and Consequences of Germany's New Citizenship Law, German Politics, 2008, 1, s. 42.

19 Jak stanowił §2 pkt. 1 Ustawy o obywatelstwie Rzeszy, przyjęty na „zjeździe wolności w Norymberdze” w 1935 r.: „Obywatelem Rzeszy jest tylko obywatel krwi niemieckiej i pokrewnej, który swym zachowaniem dowodzi, że jest skłonny i nadaje się do wiernego służenia Narodowi Niemieckiemu i Rzeszy Niemieckiej" (F. Ryszka, Państwo stanu wyjątkowego: rzecz o systemie państwa i prawa Trzeciej Rzeszy, Wrocław 1964, s. 185).

${ }^{20}$ M.M. Howard, The Politics of Citizenship in Europe, s. 121. 
czeństwo zostało posegregowane wedle obskuranckiej a zbrodniczej w konsekwencjach zasady >wartości krwi niemieckiej<"21.

Po II wojnie światowej, w poczuciu winy za zbrodnie popełnione $\mathrm{w}$ okresie nazizmu, duma narodowa i uczucia narodowe uległy znacznemu, $\mathrm{w}$ dużym stopniu kontrolowanemu, ograniczeniu. Wraz z powołaniem do życia Republiki Federalnej Niemiec jako liberalno-demokratycznego państwa narodowego, rozpoczął się proces budowania narodu obywatelskiego (civic nation) oparty na - jak to określił Jürgen Habermas - koncepcji konstytucyjnego patriotyzmu. Miała to być jedyna, możliwa do zaakceptowania $\mathrm{w}$ powojennych warunkach, forma niemieckiej tożsamości narodowej, dystansująca się od etnicznego zakorzenienia, a podkreślająca wymiar polityczny narodu. Państwo niemieckie stanowić miało nie romantyczną „Wspólnotę ducha”, lecz polityczny byt, wsparty na konstytucyjnej lojalności obywateli. Naród tworzyć miała wspólnota autonomicznych obywateli, $\mathrm{w}$ równym stopniu uprawnionych do uczestnictwa $\mathrm{w}$ prowadzonym $\mathrm{w}$ sferze publicznej dyskursie demokratycznym ${ }^{22}$.

Zważywszy na krótką i burzliwą historię niemieckiego państwa narodowego, pojawienie się w Niemczech zrębów zunifikowanej, narodowej samoświadomości zbiorowej, charakterystycznej dla takich liberalno-demokratycznych państw Europy Zachodniej jak Francja czy Anglia, wydaje się mniej oczywiste. Zwłaszcza gdy przyjmiemy, że więź narodowa jest oparta na wspólnym pochodzeniu, wywodzonym z faktycznego bądź pozornego (opartego na budowanej ex post tradycji) zamieszkiwania tego samego co nasi przodkowie terytorium. We Francji i Anglii to na wspólnocie zamieszkiwania określonego terytorium (państwa), a nie na wspólnocie korzeni biologicznych (jak w przypadku więzi etnicznej) opiera się kluczowe dla bycia członkiem danego narodu „uczestnictwo w narodowej samoświadomości zbiorowej"23. Powyższe rozumienie więzi narodowej nawiązuje do wprowadzonego przez niemieckiego historyka Friedricha Meinecke pojęcia narodu państwowego (Staatsnation) - wspólnoty tworzącej jedność z państwem poprzez odwołanie do wspólnej historii politycznej i konstytucji, składającej się z podlegających wspólnemu zestawowi praw i obowiązków obywateli ${ }^{24}$. Zdaniem Wernera Conze, naród jako wspólnotę polityczną należy rozumieć

${ }^{21}$ F. Ryszka, Państwo stanu wyjątkowego, s. 187.

22 J. Habermas, Eine Art Schadensabwicklung. Die apologetischen Tendenzenin der deutschen Zeitgeschichtsschreibung, [w:] "Historikerstreit": Die Dokumentation der Kontroverse um die Einzigartigkeit der nationalsozialistischen Judenvernichtung, München 1987, s. 75-76.

${ }^{23}$ E. Shils, Co to jest społeczeństwo obywatelskie? [w:] Europa i spoteczeństwo obywatelskie: rozmowy w Castel Gandolfo, red. K. Michalski, Kraków 1994, s. 30.

${ }^{24}$ F. Meinecke, Weltbürgertum und Nationalstaat, s. 1-7. 
(...) nie jako sumę mówiących językiem niemieckim ludzi, ale przede wszystkim jako tych, którzy swą niemieckość rozumieją nie tylko językowo czy kulturowo, lecz również politycznie - związanych z politycznymi formami manifestowania narodu ${ }^{25}$.

Warto jednak pamiętać, iż szeroka interpretacja prawa krwi, wprowadzona ustawą z 1913 roku, jako jedyny sposób nabycia obywatelstwa z mocy prawa pozostała $\mathrm{w}$ mocy. O obywatelstwie zachodnioniemieckim nadal decydowało członkostwo w Volksnation - niemieckiej wspólnocie ludzi podzielających wspólną kulturę i wartości ${ }^{26}$. Przykładem etnocentrycznego pojmowania niemieckiej tożsamości było uchwalenie w 1953 roku ustawy, która za przynależnych do narodu niemieckiego uznawała tzw. „etnicznych" Niemców. Stały za tym dwa zasadnicze powody natury politycznoprawnej. Pierwszy dotyczył zobowiązania Niemiec do zezwolenia na powrót do ojczyzny tysięcy przesiedleńców (Aussiedler) - etnicznych Niemców przybywających po wojnie z państw środkowej i wschodniej Europy. Drugi powód związany był z zimnowojennym rozpadem Niemiec i dostępem do obywatelstwa przybyszów z komunistycznej NRD (Übersiedler) oraz ich potomków. Obie polityki ujęte zostały w ramy prawne uchwalonej w 1953 ro$\mathrm{ku}$ Ustawy federalnej o wypędzonych (Bundesvertriebenen- und $\mathrm{Fl}$ üchtlingsgesetz - BVFG), która gwarantowała "prawo do powrotu” dla "etnicznych"

Niemców i ich potomków 27 . Co więcej, automatyzm przyznawania obywatelstwa przybywającym masowo do RFN w 1989 roku uciekinierom z NRD postrzega się jako ważny element presji politycznej na zjednoczenie obu części Niemiec $^{28}$. Zapoczątkowany na mocy ustawy z 1953 roku swoisty „proces etniczno-kulturowego potwierdzenia” obywatelstwa prowadził do paradoksalnej sytuacji, w której obywatele innych krajów, np. Polski, Rosji bądź Rumunii, których przodkowie wyemigrowali z Niemiec nawet setki lat wcześniej, mieli łatwiejszy dostęp do niemieckiego obywatelstwa niż długoterminowi rezydenci (tzw. Gastarbeiters i ich rodziny), często zamieszkujący RFN w drugim pokoleniu. Marc Howard pisze o - rozciągających się na okres pozjednoczeniowy - trudnościach z moralnym i ekonomicznym uzasadnieniem „uderzającego kontrastu” między sytuacją społeczno-polityczną pozbawionych dostępu do obywatelstwa, choć urodzonych w Niemczech

${ }^{25}$ W. Conze, Die deutche Nation. Ergebnis der Geschichte, Götingen 1963, s. 9; za: S. Cholewiak, Nacjonalizm w partiach zachodnioniemieckich, s. 41.

26 S. Inthorn, German Media and National Identity, New York 2007, s. 64.

${ }^{27}$ M.M. Howard, The Politics of Citizenship in Europe, s. 122.

${ }^{28}$ M.M. Howard, The Causes and Consequences of Germany's New Citizenship Law, s. 42. 
i mówiących po niemiecku Turków, a podejściem do nabywających obywatelstwo Niemiec automatycznie, choć nieznających bądź słabo znających język niemiecki i przybywających do „kraju swoich przodków” Niemców „etnicznych"29.

Jak wskazuje Miroslav Hroch, początek XIX wieku to okres dominacji w Europie tzw. „narodów państwowych”, w których naród - np. niderlandzki, francuski bądź hiszpański - stanowiła politycznie wyodrębniona wspólnota równoprawnych obywateli ${ }^{30}$. Na tym tle odmienna była sytuacja w Niemczech, w których wspólnota narodowa oparta została na więziach językowych i kulturalnych ${ }^{31}$ - zwłaszcza podkreślanej w okresie Romantyzmu konsolidacji wspólnoty narodowej wokół wielowiekowej spuścizny zwyczajów, tradycji, literatury oraz wszelkich wytworów kultury i sztuki. Jednoczące się państwo niemieckie odróżniał od Francji brak wspólnej administracji i precyzyjnie wyodrębnionego, jednolitego terytorium. Dlatego, niezbędne było „skorzystanie z takiej konwencji określenia członków narodu, która w większym stopniu odwoływałaby się do emocji niż do racjonalnych uzgodnien (np. konstytucji, jak we Francji)"32.

Od momentu zjednoczenia w 1990 roku na terytorium Niemiec obserwować można zarówno wzrost uczuć narodowych i odrodzenie dumy narodowej (a niekiedy wręcz narodowego szowinizmu), jak i wzmożoną artykulację retoryki kosmopolitycznej - potrzeby silniejszego włączenia Niemiec w kontekst europejski i światowy. Spór między zwolennikami etnocentrycznego Kulturnation (narodu kulturowego) a stronnikami obywatelskiego modelu Verfassungsnation (narodu konstytucyjnego) obecny jest w niemieckiej sferze publicznej po dziś dzień. Przedmiotem debat, prowadzonych na przełomie starego i nowego tysiąclecia, była niemiecka polityka nadawania obywatelstwa (naturalizacji), która do końca XX wieku pozostawała etnocentryczna. W przypadku Niemiec, zgodnie z ideologią nacjonalizmu, kulturowo zdefiniowana narodowość i mające wymiar prawny obywatelstwo miały ze sobą korespondować. Zrównanie tożsamości obywatelskiej z tożsamością narodową doprowadziło do traktowania polityki obywatelstwa jako polityki tożsamoścỉ3.

\footnotetext{
29 Tamże, s. 43.

${ }^{30}$ M. Hroch, Małe narody Europy, s. 98.

31 Tamże.

32 A. Bodnar, Obywatelstwo wielopoziomowe, s. 30.

33 R. Brubaker, Citizenship and Nationhood in France and Germany, s. 182.
} 


\section{Polityczno-prawne konteksty liberalizacji dostępu do obywatelstwa niemieckiego}

Sanna Inthorn wskazuje na wyraźnie etniczne podejście do definiowania narodowości niemieckiej w niemieckiej Ustawie Zasadniczej34. Oznacza ono zgodę na połączenie

horyzontalną więzią braterską" (B. Anderson) obywateli innych państw, którzy potwierdzą swoją "niemieckość”, a jednocześnie prawne i społeczne przyzwolenie na wykluczenie $\mathrm{z}$ niemieckiego państwa narodowego osób o pochodzeniu migracyjnym, urodzonych i wychowanych w Niemczech ${ }^{35}$.

Tradycyjnie oparte na prawie krwi (ius sanguinis) niemieckie obywatelstwo odwoływało się do poczucia wspólnego pochodzenia narodowego, w którego skład wchodziła „odziedziczona tożsamość kulturowa, a nawet narodowy charakter"36. Punktem zwrotnym na drodze do liberalizacji dostępu do obywatelstwa niemieckiego był wynik wyborów z 27 września 1998 roku, których zwycięzcą okazała się Socjaldemokratyczna Partia Niemiec (Sozialdemokratische Partei Deutschlands - SPD), zdobywając 40,9\% głosów. Na czele z nowym kanclerzem, Gerhardem Schröderem, SPD utworzyła rząd razem z partią Zielonych (Bündnis 90/die Grünen), powołując tym samym do życia pierwszą na poziomie federalnym lewicową, "czerwonozieloną" koalicję. Wraz z zaproponowaniem nowych rozwiązań w dziedzinie prawa imigracyjnego oraz integracyjnego, niemiecka socjaldemokracja podjęła próbę doktrynalnego przejścia: od ujmowania społeczeństwa niemieckiego w kategoriach tradycyjnego, homogenicznego ludu (Volk) do nadania mu wymiaru nowoczesnej, heterogenicznej ludności (Bevölkerung). Dotychczasowe prawo krwi zostało uzupełnione o terytorialną zasadę prawa ziemi, umożliwiającą określonym kategoriom dzieci imigrantów urodzonych na obszarze Niemiec nabycie obywatelstwa niemieckiego z mocy prawa. Jednocześnie dzieci te mogły legitymować się podwójnym obywatelstwem jedynie do 23. roku życia, kiedy pojawiała się konieczność dokonania przez nie wyboru pomiędzy obywatelstwem niemieckim a obywatelstwem

\footnotetext{
34 Jak stanowi art. 116 Ustawy Zasadniczej RFN z 23 maja 1949 r., „Niemcem (...) jest każdy, kto posiada niemiecką przynależność państwową lub kto jako uchodźca lub wypędzony narodowości niemieckiej (deutsche Volkszugehörigkeit), jego małżonek lub potomek znalazł przyjęcie na obszarze Rzeszy Niemieckiej według stanu z dnia 31 grudnia 1937 r. (źrodło: http://libr.sejm.gov.pl [dostęp: 28.03.2014]).

${ }^{35}$ S. Inthorn, German Media, s. 65.

36 Tamże.
} 
swojego państwa pochodzenia. Zgodnie z \$29 Ustawy o obywatelstwie atsangehörigkeitgezetz - StAG), brak deklaracji woli do zatrzymania obytelstwa niemieckiego skutkował jego utratą ${ }^{37}$.

Ponadto, liberalizacji uległy przepisy dotyczące naturalizacji cudzoziemców, m.in. skrócony został okres legalnego pobytu na terytorium Niemiec, wymagany do występowania z wnioskiem o nadanie obywatelstwa. Nadal jednak, jak podkreśla Peter Bultmann, naturalizacja traktowana jest jako

wyjątek od reguły, że niemieckie obywatelstwo można uzyskać wyłącznie będąc potomkiem niemieckich obywateli (ius sanguinis). (...) Cudzoziemiec, któremu przyznawane jest niemieckie obywatelstwo, powinien być już upodobniony do obywatela Niemiec. Naturalizacja ma być ukoronowaniem zakończonego procesu integracji ${ }^{38}$.

P. Bultmann zwraca także uwagę na istotne różnice we wcześniejszym stosowaniu prawa między niemieckimi krajami związkowymi, na co wskazują znaczne rozbieżności wskaźników naturalizacji w latach 1991-1996 (2-3\% w Bawarii i Badenii-Wirtembergii w stosunku do ponad 7\% w Hamburgu oraz ponad $12 \% \mathrm{w}$ Berlinie). Upraszczając, w prawicowych landach promuje się restrykcyjną interpretację prawa cudzoziemców do naturalizacji oraz głosi prymat interesu państwa nad interesem jednostkowym. W lewicowych landach przeważa większe zrozumienie dla potrzeb osób ubiegających się o nadanie obywatelstwa oraz dąży do zrównoważenia interesu państwa i jednostki.

Zmiany przepisów dotyczących obywatelstwa oraz nowe propozycje w obszarze polityki imigracyjnej wskazują, że „w niemieckiej polityce i społeczeństwie rozpoczął się proces fundamentalnych przemian dotychczasowych koncepcji tożsamości narodowej"39. Proces ten związany był z akceptacją na poziomie politycznym koncepcji Niemiec jako państwa de facto imigracyjnego (Einwanderungsland) ${ }^{40}$. Stało się tak zarówno w wyniku napływu od lat 60. XX wieku pracowników cudzoziemskich i ich rodzin, jak i w związku z postępami integracji europejskiej oraz stopniowym urzeczy-

37 Warto zwrócić uwagę, iż podwójne obywatelstwo jest warunkowo akceptowane w przypadku obywateli Unii Europejskiej, co wyraźnie wskazuje na nierówność traktowania $\mathrm{w}$ dostępie do obywatelstwa osób z krajów członkowskich UE oraz osób pochodzących z Państw Trzecich, zwłaszcza z krajów pozaeuropejskich. Powstaje zagrożenie funkcjonowania w jednym państwie dwóch kategorii obywateli. Por. K. Heilbronner, Germany's Citizenship Law under Immigration Pressure [w:] Dual Nationality, Social Rights ad Federal Citizenship in the U.S. And Europe. The reinvention of citizenship, red. R. Hansen, P. Weil, New York 2005, s. 132.

38 P.F. Bultmann, Dual Nationality and Naturalization Policies in the German Länder, [w:] Dual Nationality, s. 138-139.

39 S. Sperling, 2004, s. 144, za: S. Intorn, German Media and National Identity, s. 69.

${ }^{40}$ K. Heilbronner, Germany's Citizenship Law under Immigration Pressure, s. 130. 
wistnianiem swobody przepływu osób we Wspólnocie. W sytuacji zwiększenia się liczby cudzoziemców w Niemczech z 700 tysięcy w 1960 roku do 7,3 miliona u schyłku lat 90 . XX wieku, presja na liberalizację prawa o obywatelstwie w Niemczech była nie do uniknięcia ${ }^{41}$. Nie był to jednak proces pozbawiony kontrowersji i wewnętrznych sporów politycznych. R. Brubaker słusznie zwraca też uwagę, że rzeczywisty sprzeciw wobec imigracji osób nie-niemieckiego pochodzenia miał w mniejszym stopniu podłoże ekonomiczne bądź demograficzne, a w większym wynikał z - zakorzenionych $\mathrm{w}$ mentalności zbiorowej - przyczyn politycznych i kulturowych. Twierdzenie, iż „Niemcy nie są krajem imigracyjnym” wynikało z - dominującego do lat 90. XX wieku - etnokulturowego ukierunkowania niemieckiej polityki imigracyjnej. Naturalizacja nie była traktowana jako procedura rutynowa, ale jako rozwiązanie wyjątkowe, podejmowane wyłącznie w uzasadnionych, indywidualnych przypadkach, z uwzględnieniem istotnych interesów państwa. Wskazuje na to chociażby symptomatyczny zapis $\mathrm{w}$ administracyjnych wskazówkach dotyczących naturalizacji (Einbürgerungsrichtlinien) z lat 80. XX wieku: „Republika Federalna nie jest państwem imigracyjnym i nie dąży do zwiększenia liczby obywateli poprzez naturalizację"42. Z perspektywy obowiązującej dotychczas doktryny, a także dominującego w świadomości społecznej Niemców rozumienia obywatelstwa, zaproponowana w 1998 roku liberalizacja dostępu do obywatelstwa niemieckiego stanowiła rozwiązanie tyleż kontrowersyjne, co przełomowe.

Między wprowadzającą zmiany w 1999 roku „zielono-czerwoną" koalicją Zielonych i SPD a opozycyjną Unią Chrześcijańsko-Demokratyczną (Christlich-Demokratische Union - CDU) nie było zgody co do pierwotnej propozycji automatycznego nabywania obywatelstwa przez dzieci cudzoziemców urodzone w Niemczech (ius soli) oraz prawa do posiadania podwójnego obywatelstwa. Ponad 5 milionów podpisów pod zainicjowaną przez konserwatystów z CDU/CSU petycją, prowadzoną pod hasłem: „Tak dla integracji, Nie dla podwójnego obywatelstwa", było zarówno wskazaniem nastrojów społecznych, jak i preferencji wyborczych. Opór przeciwko liberalizacji prawa o obywatelstwie stał się elementem kampanii wyborczej do parlamentu krajowego Hesji w lutym 1999 roku, wygranej przez konserwatywną CDU. W konsekwencji zmiany układu sił w Radzie Federalnej43,

${ }^{41}$ M.M. Howard, The Politics of Citizenship in Europe, s. 125.

42 R. Brubaker, Citizenship and Nationhood in France and Germany, s. 174.

${ }^{43}$ Niem. Bundesrat - część władzy ustawodawczej RFN będąca reprezentacją krajów związkowych na szczeblu federalnym i tworząca wraz z Parlamentem Federalnym (Bundestag) tzw. "federalne ciała ustawodawcze”. W skład Rady Federalnej wchodzą wysocy przedstawiciele rządów krajowych, zwykle premierzy i bardziej znaczący ministrowie, co determinuje 
rząd federalny nie miał wystarczającej przewagi dla urzeczywistnienia proponowanych zmian. Pomysł wprowadzenia nieograniczonego prawa do podwójnego obywatelstwa nie został włączony do ostatecznej propozycji legislacyjnej. Jak wskazują obserwatorzy, choć ograniczenie procesu liberalizacji obywatelstwa samo w sobie trudno uznać za przyczynek do wzrostu etnocentryzmu w Niemczech, „odrzucenie podwójnego obywatelstwa było, przynajmniej częściowo, uzasadniane próbą zabezpieczenia etnicznokulturowej koncepcji narodowości" ${ }^{44}$. Potwierdzeniem tego może być preferencyjne traktowanie etnicznych niemieckich imigrantów, jako że to właśnie oni - tzw. "późni przesiedleńcy” (Spätaussiedler) - mogą zachować swój dotychczasowy paszport, a jednocześnie otrzymać obywatelstwo niemieckie. Obydwie strony sporu oskarżały się wzajemnie o instrumentalizację debaty o obywatelstwie niemieckim. SPD zarzucało CDU podjęcie retoryki antyimigracyjnej i budowanie poparcia politycznego na podsycaniu nastrojów ksenofobicznych w społeczeństwie. Z kolei CDU przypisywało SPD i Zielonym granie kartą migracyjną $\mathrm{w}$ celu poszerzenia potencjału wyborczego ${ }^{45}$. Abstrahując od wzajemnych obwinień, wyraźny jest brak konsensusu w Niemczech zarówno co do kwestii podwójnego obywatelstwa, jak i szerszego zagadnienia znaczenia instytucji obywatelstwa w coraz bardziej zglobalizowanym oraz zróżnicowanym kulturowo i religijnie społeczeństwie niemieckim.

Pytanie o dopuszczalność podwójnego obywatelstwa stanowi element szerszej dyskusji o integracji imigrantów w Niemczech. Jak wskazuje P. Bultmann, zakazywanie podwójnego obywatelstwa jest szkodliwe z punktu widzenia wzmacniania lojalności imigrantów wobec państwa niemieckiego i ich przynależności do wspólnoty politycznej, a „pozytywna polityka integracyjna powinna opowiadać się za podwójnym obywatelstwem"46. Strach przed "desakralizacją" obywatelstwa narodowego i zastąpieniem go instrumentalnym podejściem do obywatelstwa powinien być równoważony szczególnie istotną w Niemczech koniecznością dyskusji nad skutecznymi sposobami oraz mechanizmami włączania imigrantów i ich potomków do

silną polityczną pozycję tego organu (Niemcy wspótczesne. Zarys encyklopedyczny, red. H. Dmochowska, A. Wolff-Poweska, Poznań 1999, s. 546).

44 S. Inthorn, German Media, s. 70.

${ }^{45}$ Często powtarzanym argumentem na poparcie tej tezy jest skoncentrowanie sympatii wyborczych znaturalizowanych obywateli Niemiec po lewej stronie niemieckiej sceny politycznej: np. w wyborach parlamentarnych z 2005 r. SPD oraz partia Zielonych otrzymały aż 86\% głosów niemieckich Turków (por. Deutschtürken: 86 Prozent für Rot-Grün, Tagesspiegel, 16.10.2005, za: M.M. Howard, The Politics of Citizenship in Europe, s. 128.

46 P.F. Bultmann, Dual Nationality and Naturalization Policies, s. 154. 
narodowej wspólnoty politycznej. Kluczowe dla jednostek i grup o pochodzeniu migracyjnym jest włączenie ich do społeczeństwa obywatelskiego w wyniku przezwyciężenia wszelkich form wykluczenia, zarówno politycznego, jak i społecznego oraz kulturowego. Wejście do społeczeństwa obywatelskiego jest procesem stanowiącym warunek wstępny dla uzyskania dostępu migrantów do pełnego obywatelstwa ${ }^{47}$. Nowym elementem polityki integracyjnej miało być wsparcie imigrantów w procesie budowania ustrukturyzowanych, zintegrowanych i aktywnych społecznie wspólnot etnicznych, które pełniłyby funkcję organizacji reprezentujących interesy mniejszości i wspierających proces legitymizacji ich obecności na terytorium państwa przyjmującego. Budowanie wspólnot etnicznych powinno być powszechnie uznane za korzystne dla obu stron. Dla grup mniejszościowych (np. Turków w Niemczech) stanowi platformę artykulacji wspólnych interesów oraz wyposażenia $\mathrm{w}$ zasoby potrzebne do przeciwdziałania przejawom nierówności, rasizmu oraz dyskryminacji. $Z$ perspektywy państwa niemieckiego wspieranie wspólnot etnicznych daje szansę na integrację cudzoziemców w ramach demokratycznego społeczeństwa obywatelskiego, przezwyciężenie tendencji separatystycznych oraz wzmocnienie spójności społecznej. Jednak zarówno opinia publiczna w Niemczech, jak i niemiecka klasa polityczna mają trudności z zaakceptowaniem (urodzonych i wychowanych $\mathrm{w}$ Niemczech) "cudzoziemców" jako konstytutywnej części narodu niemieckiego ${ }^{48}$.

Etniczno-kulturowe pojmowanie narodowości i obywatelstwa w Niemczech można także dostrzec $\mathrm{w}$ formułowanych przez chadeków propozycjach oparcia polityki integracyjnej imigrantów na holistycznej i homogenicznej koncepcji kultury narodowej. Podstawą integracji imigrantów miała być zaproponowana przez CDU w 2000 roku kultura wiodąca (Leitkultur), będąca wyrazem - jak to formułuje Douglas Klusmeyer - przynależności Niemiec do zachodniochrześcijańskiej wspólnoty wartości, wspartej nie tylko na wierze chrześcijańskiej, ale także na dziedzictwie antyku, europejskiego humanizmu, oświecenia oraz judaizmu (z wyłączeniem jednakże tradycji muzułmańskiej). W opinii D. Klusmeyera, tak homogeniczny i fikcyjnie pozbawiony konfliktów obraz kultury narodowej jest nie do pogodzenia z rzeczywistą historią Niemiec, a także $\mathrm{z}$ „autentycznym zaangażowaniem w poszanowanie pluralistycznych różnic $\mathrm{w}$ nowoczesnym społeczeństwie liberalnej demokracji" 49 .

\footnotetext{
${ }^{47}$ R. Kastoryano, Türken mit deutschem Pass: sociological and political aspects of dual nationality in Germany, [w:] Dual Nationality, s. 160-161.

48 Tamże, s. 165 i 171.

${ }^{49}$ D. Klusmeyer, A 'guiding culture' for immigrants? Integration and diversity in Germany, Journal of Ethnic and Migration Studies, 2001, 27(3), s. 528.
} 


\section{Kulturnation kontra Verfassungsnation w dyskursie medialnym i naukowym}

Zderzenie między etnicznym a obywatelskim (politycznym) nacjonalizmem w Niemczech dobrze oddaje analiza publikacji prasowych, ukazujących się $\mathrm{w}$ okresie bezpośrednio przed oraz po uchwaleniu nowych przepisów o obywatelstwie (w latach 1998-1999) oraz uchwaleniu nowych zasad polityki imigracyjnej (w roku 2004). Z analiz S. Inthorn wyłania się podział przestrzeni medialnej pomiędzy dwa konkurujące ze sobą dyskursy: zwolenników Niemiec jako narodu obywatelskiego oraz tych, dla których Niemcy powinny pozostać narodem etnicznym. Pierwsi podkreślają konieczność zakorzenienia niemieckiej tożsamości narodowej w idei społeczeństwa zróżnicowanego oraz wielokulturowego. Występowanie prawicy przeciwko liberalizacji dostępu do obywatelstwa niemieckiego utożsamia się z przyjmowaniem postawy antydemokratycznej, wręcz antypatriotycznej. „Süddeutsche Zeitung" tak pisze o opozycyjnej w stosunku do proponowanych zmian polityce CSU50:

Rewolucyjna idea patriotyzmu była ukierunkowana na państwo, a nie nacjonalistyczna. Patriotami określano ludzi, którzy udowodnili swoją miłość do kraju poprzez swoje pragnienie ulepszania go na drodze reform. Naród dla nich to nie grupa, połączona cechami biologicznymi, ani też nie narzucona z góry całość, ale wspólnota, która tworzona jest w wyniku decyzji politycznych jej członków. Dlatego chrześcijańscy demokraci to anty-patrioci. Odrzucają reformę, której nasza demokracja tak bardzo potrzebuje ${ }^{51}$.

Dyskurs proreformatorski wiąże poparcie dla wielokulturowości i rozdział między tożsamością obywatelską a tożsamością kulturową z konstruowaniem Niemiec jako narodu demokratycznego. Potwierdzeniem przywiązania Niemiec do wartości demokratycznych jest budowanie niemieckiej tożsamości narodowej wokół wartości politycznych.

W sporze między dwiema koncepcjami niemieckiej tożsamości: jednej z przewagą elementów etniczno-kulturowych, drugiej - wspartej przede wszystkim na elementach obywatelskich, sięga się także do argumentów historycznych, w szczególności nacjonalistycznej polityki pangermanizmu oraz późniejszej, narodowo-socjalistycznej polityki czystości rasowej i eksterminacji nie-niemieckich grup etnicznych. Do nieudanego pożegnania z przeszłością odwołuje się m.in. artykuł w „Berliner Zeitung” z 1998 roku, w którym czytamy:

\footnotetext{
${ }^{50}$ CSU - Niemcy wspótczesne. Zarys encyklopedyczny.

51 S. Inthorn, German Media, s. 74.
} 
Jedną z wielkich porażek twórców ustawy zasadniczej z 1949 r. jest brak korekty nacjonalistycznego charakteru niemieckiego prawa o obywatelstwie, które stało się nieszczęściem Europy ${ }^{52}$.

W medialnym dyskursie przeciwników liberalizacji dostępu do obywatelstwa niemieckiego dominuje konstruowanie niemieckości w pierwszej kolejności opartej na komponentach etnicznych, a dopiero w drugiej - opartej na elementach postawy obywatelskiej. Tolerowanie podwójnego obywatelstwa jest przez konserwatystów przedstawiane jako zagrożenie dla integracji (rozumianej jako asymilacja i zgoda na przyjęcie niemieckich wartości kulturowych). Dominację kulturowego rozumienia narodu można dostrzec w oficjalnych wypowiedziach prawicowych polityków, którzy - jak były premier Bawarii z ramienia CSU, Günther Beckstein - będą twierdzić, że „nie ma czegoś takiego, jak podwójna lojalność”, a „podwójny paszport to zagrożenie dla integracji. Nowy obywatel powinien się w pełni opowiedzieć za swoją nową ojczyzną (neuen Heimat)"53. Przynależność do narodu niemieckiego jest tu ukazywana jako członkostwo we wspólnocie obywateli, rozumianej jako wspólnota organiczna.

Powiązanie obywatelstwa niemieckiego z tożsamością kulturową sprawia, że zróżnicowanie kulturowe w Niemczech przedstawiane jest w mediach jako zagrożenie dla spójności społecznej i tożsamości politycznej Niemiec jako państwa demokratycznego. S. Inthorn cytuje „Die Zeit”, w którym zgodę na podwójne obywatelstwo utożsamia się z zagrożeniem ze strony takich sił antydemokratycznych jak Milli Görüşs ${ }^{54}$ - największa organizacja zrzeszająca mniejszość turecką w Niemczech, oskarżana o propagowanie islamskiego ekstremizmu oraz „podważanie rodzimego porządku oraz tradycji" 55. Łącząc działalność kontrowersyjnych organizacji mniejszościowych

52 Tamże, s. 75.

53 "Die Welt" z 04.08.2002, cytat za: D. Naujoks, Klassische Einwände und mögliche Gegenargumente,

(http://www.bpb.de/gesellschaft/migration/kurzdossiers/57278/einwa ende? $\mathrm{p}=$ all [dostęp: 12.03.2014]).

${ }^{54}$ Muzułmańska Wspólnota „Pogląd Narodowy” (Islamische Gemeinschaft Milli Görüş IGMG) powstała w 1995 r. na bazie innych organizacji muzułmańskich. Uważana jest obecnie za drugą co do wielkości organizację muzułmańską w Niemczech. IGMG mająca swoją siedzibę w Bonn zrzesza ponad 25 tysięcy członków oraz ponad 270 związków meczetowych. Ze względu na kontrowersyjną działalność polityczną organizacji, które były poprzedniczkami IGMG i weszły w jej skład w połowie lat 90. XX wieku, pozostaje ona pod stałym nadzorem niemieckich służb bezpieczeństwa (K. Matros, Muzutmanie w europejskiej przestrzeni publicznej na przykładzie miast niemieckich, [w:] Zachód a świat islamu - zrozumieć Innego, red. I. Kończak, M. Woźniak, Łódź 2012, s. 36).

55 S. Inthorn, German Media, s. 80. 
z problemem podwójnego obywatelstwa i „konfliktu lojalności”, powiela się medialny obraz całej społeczności imigrantów z Turcji jako grupy co do zasady separującej się, odrzucającej język i tradycje niemieckie, a przez swój sprzeciw wobec integracji (asymilacji) będącej ciężarem zarówno dla siebie samych (dotkniętych samowykluczeniem), jak i dla niemieckiej większości. W eksponowanym w mediach, będącym konsekwencją podziałów politycznych, starciu między etnicznym a obywatelskim wyobrażeniem narodu, przewagę zyskuje to pierwsze. Medialne zwycięstwo Volksnation zostało oparte na propagowaniu strachu przed "obcymi” kulturami, które stanowią zagrożenie dla niemieckiej tożsamości narodowej. Jak podsumowuje S. Inthorn,

naznaczony swoją tożsamością kulturową Inny jawi się jako zagrożenie, ciężar zbyt odmienny od nas samych, aby być w stanie - chociażby częściowo - dostosować się do oczekiwań, zgodnych z niemieckimi wartościami politycznymi ${ }^{56}$.

Zdaniem badaczy krytycznie nastawionych do takiego ukierunkowania dyskursu o mniejszościach, potwierdzeniem przywiązania Niemiec do wartości demokratycznych i autentycznego zaakceptowania swojego statusu państwa imigracyjnego jest odejście od uzależniania przynależności do narodu niemieckiego od członkostwa we wspólnocie obywateli, rozumianej jako wspólnota organiczna (etniczna). W prawie i polityce powinny zostać wypracowane czytelne granice między narodowością a obywatelstwem. Narodowość powinno się utożsamiać z etnicznością, opartą na tożsamości związanej z krajem pochodzenia (country of origin) i konstruowanej na podstawie czynników religijnych i kulturowych. Obywatelstwo powinno stać się uprawnieniem związanym $\mathrm{z}$ krajem pobytu (country of residence) i postrzeganym jako status prawny, oparty na zobowiązaniu do przestrzegania zasad konstytucji i posługiwania się wspólnym językiem ${ }^{57}$. Obywatelstwo wyraża zatem więź polityczną, a narodowość - „więź emocjonalną, więź pochodzenia, jaka łączy jednostkę z grupą społeczną narodu"58.

Jednocześnie, należy pamiętać o - sygnalizowanej przez F. Meinecke już na początku XX wieku - współzależności między obywatelskim i kulturowym rozumieniem narodu. Narodowość może odnosić się zarówno do statusu prawnego jednostki (jej przynależności państwowej oraz zakorzenienia w działającej dla wspólnego dobra wspólnocie obywateli), jak i do pochodzenia etnicznego jednostki. W tym drugim przypadku „narodowość wyraża się w związkach między osobą fizyczną a grupą etniczną w odniesie-

\footnotetext{
56 Tamże, s. 82.

57 R. Kastoryano, Türken mit deutschem Pass, s. 161.

58 A. Bodnar, Obywatelstwo wielopoziomowe, s. 31.
} 
niu do tożsamości jednostki, dziedziczonej tradycji i identyfikacji z szerszą grupą"59.

Narodowość jako związek prawny jednostki z państwem istnieje zatem zarówno w wymiarze zewnętrznym (nationality), jak i wewnętrznym (citizenship). Podczas gdy obywatelstwo wewnętrzne funkcjonuje $\mathrm{w}$ wymiarze narodowym (m.in. jako prawo dostępu do instytucji państwowych), obywatelstwo zewnętrzne, czyli narodowość, realizowane jest $\mathrm{w}$ wymiarze międzynarodowym (m.in. jako prawna przynależność do określonego narodu i wynikające $z$ tego konsekwencje $w$ relacjach międzypaństwowych) ${ }^{60}$. Mimo iż obywatelstwo wewnętrzne ma wyraźniejszy wymiar partycypacyjny, a obywatelstwo zewnętrzne jest rozumiane $\mathrm{w}$ większym stopniu $\mathrm{w}$ sensie kulturowym, jednak pojęcia te używane są zamiennie, jako desygnaty prawnego wymiaru członkostwa w państwie ${ }^{61}$. Dwoistość rozumienia obywatelstwa w państwie narodowym nie zmienia faktu, iż - jak podkreśla Jacek Jagielski - „oba te pojęcia odzwierciedlają to samo zjawisko, tj. prawny związek jednostki z państwem"62. W przypadku państw anglosaskich, a także Francji (nationalité - citoyennetê) można mówić o wyraźnym podobieństwie znaczeniowym między obywatelstwem jako przynależnością państwową (nationality) a obywatelstwem jako członkostwem we wspólnocie politycznej (citizenship) ${ }^{63}$. R. Brubaker pisze wręcz o

semantycznym zachodzeniu na siebie (semantic overlap) narodowości i obywatelstwa $\mathrm{w}$ języku angielskim i francuskim, mającym swoje źródło w politycznym definiowaniu narodu i stopieniu się koncepcji państwa, narodu i suwerennego ludu we francuskiej, angielskiej i amerykańskiej 64 tradycji politycznej, w efekcie oddziaływania rewolucji założycielskich ${ }^{65}$.

Sytuacja w Niemczech różni się znacznie od kontekstu anglosaskiego i francuskiego, chociażby ze względu na brak "rewolucyjnej krystalizacji” egalitarnej, demokratycznej i narodowej koncepcji obywatelstwa. Obywatel-

59 Tamże, s. 34.

60 S.L. Robertson, Globalization, Rescaling National Education Systems and Citizenship Regimes, [w:] Changing Notions of Citizenship Education in Contemporary Nation-states, red. K. Roth, N. Burbules, Rotterdam 2007, s. 3.

61 R. Brubaker, Citizenship and Nationhood in France and Germany, s. 50.

62 J. Jagielski, Obywatelstwo polskie. Zagadnienia podstawowe, Warszawa 1998, s. 12.

63 A. Bodnar, Obywatelstwo wielopoziomowe, s. 35.

64 Ze względu na brak w kontekście amerykańskim koncepcji państwa narodowego, właściwej dla Europy kontynentalnej, „semantyczne zachodzenie na siebie” narodowości i obywatelstwa jest w przypadku Stanów Zjednoczonych „odbiciem politycznej definicji narodu i połączenia koncepcji narodu i suwerennego ludu” (R. Brubaker, Citizenship and Nationhood in France and Germany, s. 201).

65 Tamże, s. 50. 
stwo zewnętrzne określa się niemieckim terminem Staatsangehörigkeit, tłumaczonym jako „przynależność państwowa” i utożsamianym z obywatelstwem w znaczeniu międzynarodowym - ogólnej, prawnej przynależności osoby do określonego państwa. Z kolei, wewnętrzny charakter prawnego związku jednostki z państwem oddaje niemiecki termin Staastsbürgerschaft członkostwo we wspólnocie politycznej, której granice wyznaczają prawa i obowiązki obywateli partycypujących w życiu politycznym wspólnoty. Istnieje jeszcze trzeci rodzaj członkostwa w państwie, mający charakter pozaprawny, etno-kulturowy i oparty na tożsamościowych powiązaniach między osobą fizyczną a grupą etniczną/narodową. Członkostwo we wspólnocie narodowej określa się niemieckim terminem Volkszugehörigkeit albo Nationalität. Wszystkie trzy wymiary członkostwa w państwie - formalne, partycypacyjne i etniczno-kulturowe - są w języku niemieckim wyraźnie zróżnicowane semantycznie. Jak podkreśla R. Brubaker, jest to wyraz niezależnego, a czasem wręcz antagonistycznego przebiegu w Niemczech trzech zasadniczych procesów: budowania struktur państwowych, scalania się wspólnoty narodowej oraz wprowadzania demokracji 66 .

Postnarodową kulturę polityczną, funkcjonującą w Niemczech od okresu powojennego, można wyjaśniać poprzez odwołanie do konfliktu pomiędzy partykularystyczną (narodową) a uniwersalistyczną (ponadnarodową) orientacją polityczną. Zwycięstwem tej drugiej była opisywana w niniejszym tekście rezygnacja $\mathrm{z}$ obowiązującej przez dekady $\mathrm{w}$ niemieckim prawie o obywatelstwie zasady ius sanguinis. Polityczna reorientacja ku postnarodowości, zapoczątkowana już w okresie powojennych Niemiec (zachodnich), po dziś dzień powoduje problemy ze zrozumieniem i konceptualizacją tożsamości niemieckiej zarówno dla samych Niemców, jak i dla obserwatorów z zewnątrz.

\section{BIBLIOGRAFIA}

Bodnar A., Obywatelstwo wielopoziomowe. Status jednostki w europejskiej przestrzeni konstytucyjnej, Wydawnictwo Sejmowe, Warszawa 2008.

Brockmann S., Nuremberg. The Imagniary Capital, Camden House 2006.

Brubaker R., Citizenship and Nationhood in France and Germany, Harvard University Press, Cambridge, Massachusetts, London 1992.

Bultmann P.F., Dual Nationality and Naturalization Policies in the German Länder, [w:] Dual Nationality, Social Rights ad Federal Citizenship in the U.S. and Europe. The reinvention of citizenship, red. R. Hansen, P. Weil, Berghahn Books, New York 2005.

Cholewiak S., Nacjonalizm w partiach zachodnioniemieckich, Wydawnictwo Ministerstwa Obrony Narodowej, Warszawa 1984.

66 Tamże. 
Conze W., Die deutche Nation. Ergebnis der Geschichte, Götingen 1963.

Deutsch K.W., Nationenbildung - Nationalstaat - Integration, Düsseldorf 1972, w: NationNationalismus-nationale Identität, red. D. Weidinger, Bundeszentrale für politische Bildung, Bonn 1998.

Habermas J., Eine Art Schadensabwicklung. Die apologetischen Tendenzenin der deutschen Zeitgeschichtsschreibung, [w:] "Historikerstreit": Die Dokumentation der Kontroverse um die Einzigartigkeit der nationalsozialistischen Judenvernichtung, Piper Verlag, München 1987.

Heilbronner K., Germany's Citizenship Law under Immigration Pressure, [w:] Dual Nationality, Social Rights ad Federal Citizenship in the U.S. and Europe. The reinvention of citizenship, red. R. Hansen, P. Weil, Berghahn Books, New York 2005.

Howard M.M., The Causes and Consequences of Germany's New Citizenship Law, German Politics, 2008, 1.

Howard M.M., The Politics of Citizenship in Europe, Cambridge University Press, New York 2009.

Hroch M., Małe narody Europy. Perspektywa historyczna, przekł. G. Pańko, Zakład Narodowy im. Ossolińskich, Wrocław - Warszawa - Kraków 2003.

Inthorn S., German Media and National Identity, Cambria Press, New York 2007.

Jagielski J., Obywatelstwo polskie. Zagadnienia podstawowe, Wydawnictwo Prawnicze, Warszawa 1998.

Kastoryano R., Türken mit deutschem Pass: sociological and political aspects of dual nationality in Germany, [w:] Dual Nationality, Social Rights ad Federal Citizenship in the U.S. and Europe. The reinvention of citizenship, red. R. Hansen, P. Weil, Berghahn Books, New York 2005.

Klusmeyer D., A 'guiding culture' for immigrants? Integration and diversity in Germany, Journal of Ethnic and Migration Studies, 2001, 27(3).

Matros K., Muzutmanie w europejskiej przestrzeni publicznej na przykładzie miast niemieckich, [w:] Zachód a świat islamu - zrozumieć Innego, red. I. Kończak, M. Woźniak, Katedra Bliskiego Wschodu i Afryki Północnej UŁ, Łódź 2012.

Meinecke F., Weltbürgertum und Nationalstaat, München - Berlin 1919, w: NationNationalismus-nationale Identität, red. D. Weidinger, Bundeszentrale für politische Bildung, Bonn 1998.

Naujoks D., Klassische Einwände und mögliche Gegenargumente, 01.11.2009 (http://www. bpb.de/gesellschaft/migration/kurzdossiers/57278/einwaende?p=all [dostęp:12.03. 2014]).

Niemcy wspótczesne. Zarys encyklopedyczny, red. H. Dmochowska, A. Wolff-Poweska, Instytut Zachodni, Poznań 1999.

Paluszyński T., Historia Niemiec i państw niemieckich. Zarys dziejów politycznych, Oficyna Wydawnicza Wyższej Szkoły Języków Obcych, Poznań 2006.

Robertson S.L., Globalization, Rescaling National Education Systems and Citizenship Regimes, [w:] Changing Notions of Citizenship Education in Contemporary Nation-states, red. K. Roth, N. Burbules, Sense Publishers, Rotterdam 2007.

Ryszka F., Państwo stanu wyjątkowego: rzecz o systemie państwa i prawa Trzeciej Rzeszy, Zakład Narodowy im. Ossolińskich, Wrocław 1964.

Shils E., Co to jest społeczeństwo obywatelskie? [w:] Europa i społeczeństwo obywatelskie: rozmowy w Castel Gandolfo, red. K. Michalski, Społeczny Instytut Wydawniczy Znak, Kraków 1994.

Tyszkiewicz J., Czapiewski E., Historia powszechna. Wiek XX, Wydawnictwo Naukowe PWN, Warszawa 2012. 